\title{
Maturity Indices of Indian Horse-Chestnut (Aesculus indica Colebr) Seeds Under Temperate Kashmir Conditions
}

\author{
Mumtaz Majeed*, M.A. Khan**, A.H. Mughal*** and Altamash Bashir* \\ *Post Graduate in Forestry \\ **Dean Faculty of Forestry \\ ***Associate Professor \\ Faculty of Forestry. Sher-e-Kashmir University of Agricultural Science and \\ Technology of Kashmir. Shalimar, 191121, INDIA
}

\begin{abstract}
The study on maturity indices of Aesculus indica seeds was conducted under temperate Kashmir conditions. Seed collection started from 15th July and continued till the maturation of seeds in the month of December. The seeds were harvested fortnightly from identified trees and on each collection date maturity parameters viz. seed colour, seed weight, moisture content, seed dimension, specific gravity, and germination percentage were recorded.

The study revealed that at the time of maturity (Nov-Dec) the seed colour is shiny chocolate brown, having a moisture content of 58.37 per cent and a specific gravity of 0.82 . Germination percentage was maximum $(80 \%)$ at its maturity with maximum seed weight of $52.03 \mathrm{~g} / \mathrm{seed}$. Besides the seeds should be collected before their natural disposal.
\end{abstract}

Key words: Aesculus indica; maturity indices; seed weight; seed colour; specific gravity

\section{Índices de Maturidade em Sementes de Aesculus indica Colebr, no Clima Temperado de Cachemira}

Sumário. O estudo sobre índices de maturidade em sementes de Aesculus indica efectuou-se no clima temperado de Cachemira. A colheita de semente começou a 15 de Julho e continuou até à maturação, no mês de Dezembro. Foi feita quinzenalmente, em árvores identificadas, e em cada data registaram-se parâmetros de maturidade da semente, tais como cor, peso, percentagem de humidade, dimensão, peso específico e percentagem de germinação.

O estudo revelou que na altura da maturação (Novembro-Dezembro) a cor da semente era castanho escuro brilhante, com $58,37 \%$ de humidade e peso específico de 0,82 . A percentagem de germinação era máxima (80\%) na maturidade, com peso máximo de 52,03g/semente. Além disso, as sementes devem ser colhidas antes que se verifique a sua queda natural.

Palavras-chave: Aesculus indica; índices de maturidade; peso da semente; cor da semente; peso específico

Indices de Maturité des Graines de Aesculus indica Colebr sous le Climat Tempéré de Cachemire

Résumé. L'étude concernant l'indice des maturité de graines de Aesculus indica a été efectuée dans les conditions climatiques tempérées de Cachemire. La récolte des graines a commencée le 
15 juillet et s'est prolongée jusqu'à la maturité, au mois de décembre. Tous les quinze jours on procéda à la récolte de graines sur des arbres marqués, et à chaque date des paramètres de maturité des graines furent enregistrés, tels que la couleur, poids, taille, poids spécifique et pourcentage de germination.

Ce travail a démontré que, en période de maturation (novembre-décembre) la couleur de la graine était marron brillant, ayant $58.37 \%$ d'humidité et 0.82 de poids spécifique. Le pourcentage de germination était maximum à la maturité, avec un poids maximum de $52.03 \mathrm{~g} /$ graine. Les graines doivent être récoltées avant qu'elles ne tombent des arbres.

Mots clés: Aesculus indica; indices de maturité; poids de la graine; couleur de la graine; poids spécifique

\section{Introduction}

Indian Horse-chestnut (Aesculus indica Colebr) locally known as 'Hanudun' is found in temperate regions of Asia, Europe and America, partially East Asia, North Western Himalaya, North America with altitude varying from 900-3600m (SANTAPAU and HENERY, 1973).

The tree is medium to large sized, with canopy round to broadly spreading. Leaves are digitate/palmately compound with undulate margin and are opposite to sub-opposite in arrangement. Flowers are white to creamy white in colour. Fruit is a capsule and is light brown with green patches in colour. Seed is dark shiny brown in colour with dull white scar.

The tree is being widely used for afforestation purpose by forest Department in Kashmir valley. The tree is planted for ornamental purpose. Its leaves and seeds are used as fodder, wood as small timber, branches for making charcoal etc. In forests its seeds are eaten by monkeys, bears and other wild animals as fodder.

Seeds of Aesculus indica are big in size with high moisture contents and fall under the category of temperate recalcitrant seeds and remain viable for about one month only. Seeds being recalcitrant need to be collected well in time so that they can be stored under proper conditions, as any delay in collection may result in the loss of viability. Therefore maturity indices studies are important because of the fact that the knowledge of exact stage and time of seed maturity is essential for collection of abundant quantity of healthy and vigorous seeds. Fully mature seeds collected at appropriate time retain viability longer than the seeds collected when immature (HARRINGTON, 1970 and STEIN et al., 1974).

Dipterocarpus retusus (Hollong) seeds collected during first half of March were found to be most favourable for maximum germination (THAKUR et al., 2000).

Change in colour of fruit provide a simple and in some species reliable criteria for judging seed maturity (WILLIAM, 1985). A relationship is often established between seed colour and maturity which is often used to identify physiological maturity of tree seeds as in Plantanus occidentalis (BONNER, 1972) and in Quercus spp. (BONNER, 1974).

SINGH and KACHARI, 2006 reported that the germination percentage of seeds increased with decrease in specific gravity and moisture content in cones of Pinus kesiya (Khasi pine).

Immature seeds die if they are allowed to dry out (HARRINGTON, 1972). 
Thus, fruit collection should be started only when the seeds are sufficiently mature corresponding to the indicators of maturity for individual species.

\section{Materials and methods}

The studies were carried out at post graduate level in the Faculty of Forestry, SKUAST-K, Shalimar, during the year 2006. The experimental site lies between $74.89^{\circ}$ longitude and $34.08^{\circ}$ latitude at an altitude of about $1587 \mathrm{~m}$ amsl. The soil is silty loam type.

The climate in general is temperate; with severe winter extending from December to March. The region faces a wide temperature range from a minimum of $-8.0^{\circ} \mathrm{C}$ in winter to a maximum of $33^{\circ} \mathrm{C}$ in the summers. Winter frost is common and medium to heavy snowfall is also witnessed. The area receives an annual precipitation of $676-1193 \mathrm{~mm}$, with an average of $944.6 \mathrm{~mm}$.

The optimal time for harvest is when a large quantity of viable germinable seeds can be collected. In order to determine the best time for collection of seeds, they were collected from preidentified phenotypically superior trees. The seeds were picked from mid of July till their maturation at an interval 15 days and were subjected to germination test, specific gravity, moisture content, seed weight, change in fruit/seed coat color and seed dimensions.

The germination test was performed in petriplates lined with double fold germination paper at bottom. The seeds were placed sparsely in Petri plates and moistened. The plates were incubated at $25 \pm 1^{\circ} \mathrm{C}$ in B.O.D incubator for a period of 21 days. The plates were kept moist and inspected regularly. Seeds were considered to have germinated as soon as radical emerged.

Various parameters were recorded and analysed as under:

i) The germination percentage was calculated as:

$$
\text { Germination \%age }=\frac{\begin{array}{l}
\text { No. of seeds } \\
\text { germinated }
\end{array}}{\text { Total No. of seeds }} \times 100
$$

ii) Specific gravity of seeds was determined by water displacement method as described by (BARNET, 1979).

iii) Seed weight (g) was determined with the help of sensitive top pan balance. Eight replicates of hundreds each were used for determining seed weight.

iv) Moisture content was determined by using host air oven on fresh weight basis as per (ISTA, 1993) recommendations.

v) Fruit/ seed coat colour was estimated on ocular basis.

vi) Seed dimensions were measured in terms of mid diameter ( $\mathrm{mm}$ ) and length $(\mathrm{mm})$ with the help of digital calliper.

100 seeds in four replicates were used for taking observations.

\section{Results and discussion}

Studies carried with respect to maturity indices showed that Aesculus indica Colebr comes into flowering in the month of May-June depending upon climatic, edaphic and topographic factors of the locality. The trees at lower altitudes start flowering earlier in late May while those at higher altitudes with cooler weather conditions start flowering by early June.

The data collected and presented in Table - 1 (Figure 1) showed that fruit colour, seed coat colour and specific 
gravity had a relationship with the maturity of the seeds. The colour changes in Indian Horse-chestnut seed coat was observed from white, when immature to various shades of white with brown patches to shiny chocolate brown of the mature seed. (Plate 1-4). Germination in seeds started when seed coat colour was brown (24 percent) reaching to a maximum of 80 percent when seed coat colour was shiny cholocate brown. Change in colour of fruits provide a simple and in some species reliable criteria for judging seed maturity (WILLIAM, 1985). Colour change is directly related to the maturity of the seeds. In case of Bauhinia restua (semla), change in fruit colour from green to dark red and the seed colour from green to whitish brown is useful indicator of seed maturity (UPADHAYAY et al., 2006). Seeds of Aesculus hippocastanum also undergo characterristic changes in the seed coat colour from white to brown as maximum seed fall approaches (THOMPSETT and PRITCHARD, 1993). Changes in colour of fruits of Junipers to deep blue have also been reported by STOECKLER and SLABAUGH, 1965.

The specific gravity of the seeds is another quick and reliable method of judging maturity of the seed. The specific gravity of the Aesculus indica seeds decreased from 1.18 (immature) to 0.82 with the maturity of the seed Table 1 (Figure 1) germination was recorded when the specific gravity of the seed was 1.18 (Max.) and fruit was light brown in colour and seed coat colour was white. However the maximum of 80 percent germination was recorded (Figure 1) when specific gravity was between 0.82 to 0.83 and colour of seed had turned to shiny chocolate brown. No germination was recorded at first six collection dates i.e from $15^{\text {th }}$ July to $1^{\text {st }}$ October (Table 1).

Table 1 - Maturity indices of seeds of Indian Horse-chestnut (Aesculus indica Colebr) collected on different dates during 2006

\begin{tabular}{|c|c|c|c|c|c|c|c|}
\hline \multirow{2}{*}{\multicolumn{2}{|c|}{ Date of Collection }} & \multicolumn{2}{|c|}{ Colour } & \multirow{2}{*}{$\begin{array}{l}\text { Specific } \\
\text { Gravity }\end{array}$} & \multicolumn{2}{|c|}{$\begin{array}{c}\text { Seed } \\
\text { Dimensions }\end{array}$} & \multirow{2}{*}{$\begin{array}{c}\text { Germination } \\
(\%)\end{array}$} \\
\hline & & \multirow{2}{*}{$\begin{array}{c}\text { Fruit } \\
\text { Light brown }\end{array}$} & \multirow{2}{*}{\begin{tabular}{|r|} 
Seed Coat \\
White
\end{tabular}} & & $\begin{array}{c}\text { Diameter } \\
\text { (mm) }\end{array}$ & $\begin{array}{l}\text { Length } \\
\text { (cm) }\end{array}$ & \\
\hline & $15^{\text {th }}$ July & & & 1.18 & 23.19 & 30.56 & 0 \\
\hline $2^{\text {nd }}$ & $1^{\text {st }}$ August & -do- & -do- & 1.10 & 23.40 & 30.56 & 0 \\
\hline $3^{\text {rd }}$ & $15^{\text {th }}$ August & -do- & Creamy white & 1.08 & 28.88 & 36.18 & 0 \\
\hline $4^{\text {that }}$ & $1^{\text {st }}$ September & -do- & -do- & 1.08 & 36.81 & 43.00 & 0 \\
\hline $5^{\text {th }}$ & $15^{\text {th }}$ September & -do- & $\begin{array}{c}\text { Creamy white } \\
\text { with brown } \\
\text { patches }\end{array}$ & 0.98 & 42.20 & 45.55 & 0 \\
\hline $6^{\text {th }}$ & $1^{\text {st }}$ October & $\begin{array}{l}\text { Light brown with } \\
\text { green patches }\end{array}$ & -do- & 0.87 & 45.13 & 48.64 & 0 \\
\hline 7 th & $15^{\text {th }}$ October & -do- & Brown & 0.85 & 46.87 & $49 \ldots 96$ & 24 \\
\hline $8^{\text {th }}$ & $1^{\text {st }}$ November & -do- & $\begin{array}{c}\text { Shiny chocolate } \\
\text { brown }\end{array}$ & 0.84 & 46.91 & 49.98 & 50 \\
\hline $9^{\text {th }}$ & $15^{\text {th }}$ November & -do- & -do- & 0.83 & 46.98 & 49.98 & 80 \\
\hline $10^{\text {th }}$ & $1^{\text {st }}$ December & -do- & -do- & 0.82 & 46.98 & 49.98 & 80 \\
\hline
\end{tabular}

Dia $(\mathrm{mm})$ - mid dia of seed; Length (mm) - length of seed 


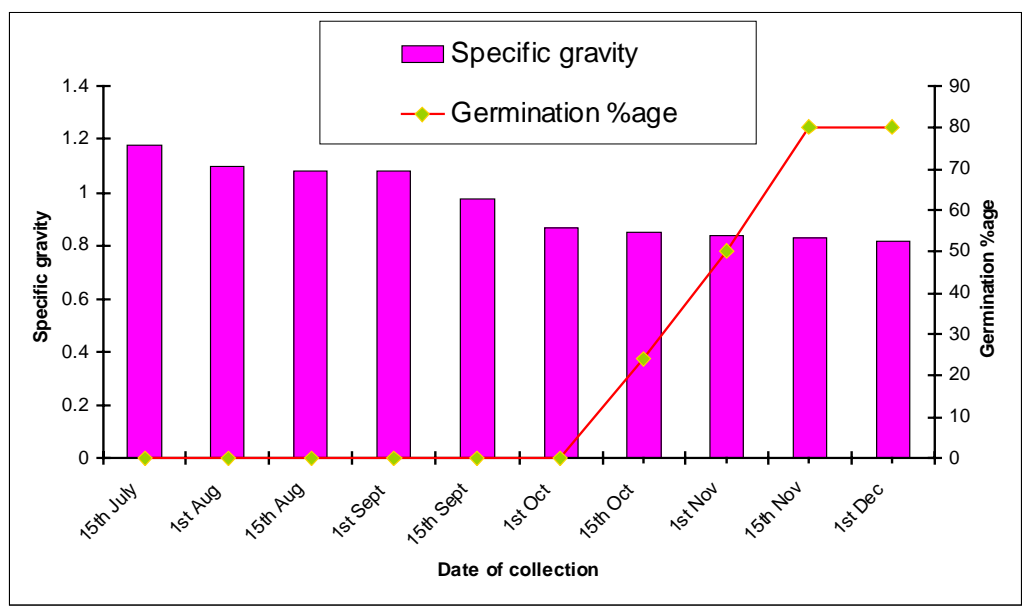

Figure 1 - Effect of collection dates on specific gravity and germination percentage of Aesculus indica seeds

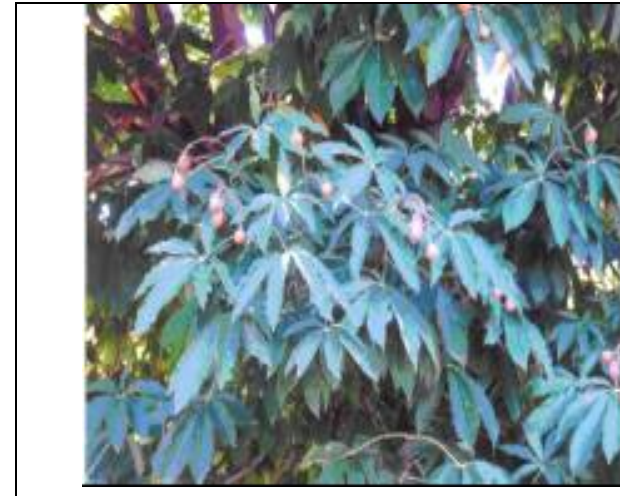

Plate 1 - Fruit set of Indian Horse-chestnut tree stage

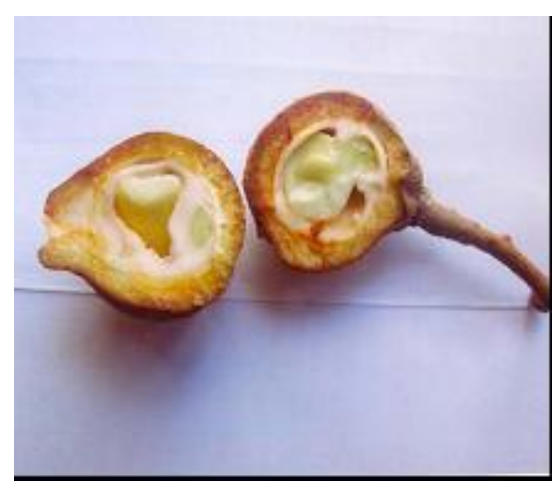

Plate 3 - Vertical section of immature chestnut Indian Horse-chestnut seed showing mucilaginous endosperm

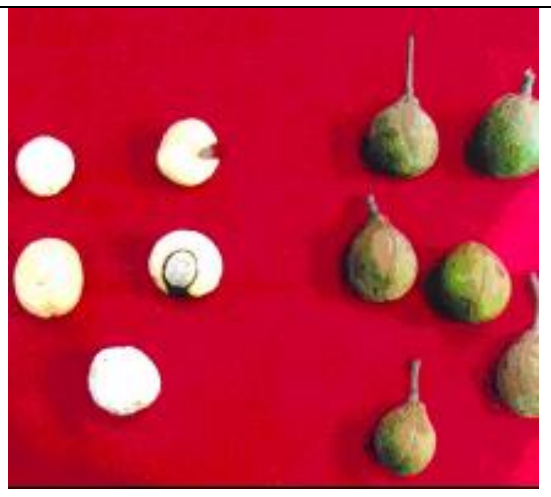

Plate 2 - Indian Horse-chestnut fruits/seeds showing immature

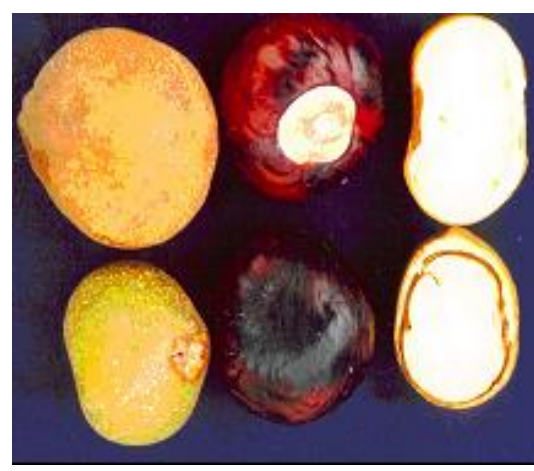

Plate 4 - Indian Horse- chestnut fruits/seeds at showing mature stage 
Twenty four percent of seeds germinated on the $7^{\text {th }}$ date of collection i.e on $15^{\text {th }}$ October when specific gravity was 0.85 and increased to a constant of 80 per cent from $15^{\text {th }}$ November to $1^{\text {st }}$ December with specific gravity of $0.83-0.82$. Germination percentage increases with decrease in seed/fruit specific gravity has been reported (SINGH, 1989). In Celtis australis (Hackberry) germination percentage increased from $0-23$ per cent as the specific gravity decreased from 1.22 to 1.03 respectively (SINGH, 2006).

The studies were further conducted on relationship of seed weight and moisture percentage on maturation of seed. The data presented in Table 2 shows that seed weight in India Horsechestnut seeds increased towards maturity. No germination recorded when the seed weight was between 7.50 to $32.22 \mathrm{~g}$.

Germination percentage of $24-50$ per cent was recorded when the seed weight was between 39.30 to $44.98 \mathrm{~g}$. respectively. However, the maximum of 80 percent germination was observed when the seed weight was recorded as $52.03 \mathrm{~g}$ on last two collection dates i.e on $15^{\text {th }}$ November and $1^{\text {st }}$ December. Relative high seed weight is often desirable since it is correlated with rapid germination and good seedling establishment (GRIFFIN, 1972; SORENSEN and CAMPBELL, 1993).

Studies further revealed that moisture content and germination percentage are negatively related (Table 2). The germination percentage increased with decrease in moisture percentage. No germination was observed when the moisture content was recorded between 76.69 to 66.76 percent (15-07-2006 to 0110-2006). However, maximum germination of 80 percent was recorded on $15^{\text {th }}$ November when the moisture percent was lowest i.e 58.37 per cent. Decreased moisture content is a characteristic feature of maturation in Dalbergia sisso, moisture loss coincide with maturity (JOSHI, 2000). The maturity indices for harvesting pods in Albizzia lebbeck (Kokko tree) is decrease in moisture content of seed and increase in its dry weight (BHARDWAJ et al., 2002). SINGH (2006) reported the increase in germination percentage from $0-23$ percent as the moisture content reduced from 52.19 to 31.63 percent in case of Celtis australis (Hack berry). Studies further showed that the seed dimensions i.e. mid diameter $(\mathrm{mm})$ and length $(\mathrm{mm})$ were low when seeds immature (Table 1 ) and showed increased trend as the seeds reached full maturity. When seeds were collected on $1^{\text {st }}$ collection date ( $\left.15^{\text {th }} \mathrm{July}\right)$, their length and mid-diameter were 30.56 and $23.19 \mathrm{~mm}$ respectively. As the seeds matured fully their dimensions were $49.98 \mathrm{~mm}$ long and $46 . \mathrm{mm}$ mid diameter.

Thus, the studies conducted on maturity indices of Indian Horsechestnut seeds revealed that proper stage of harvesting seeds was when the seed coat colour changed from white to brown or shiny chocolate brown along with decline in moisture percentage and specific gravity of the seed. The maximum of 80 percent germination was therefore recorded on $9^{\text {th }}$ and $10^{\text {th }}$ collection i.e. from $15^{\text {th }}$ November onwards. 
Table 2 - Relationship of seed weight and moisture content on germination percentage of Indian Horse-chestnut (Aesculus indica Colebr) seeds during 2006 at different stages of maturity

\begin{tabular}{|c|l|l|c|c|c|}
\hline $\begin{array}{c}\text { S. } \\
\text { No. }\end{array}$ & \multicolumn{2}{|c|}{ Date of Collection } & $\begin{array}{c}\text { Seed weight } \\
(\mathbf{g})\end{array}$ & $\begin{array}{c}\text { Moisture } \\
(\%)\end{array}$ & $\begin{array}{c}\text { Germination } \\
(\mathbf{\%})\end{array}$ \\
\hline 1. & $1^{\text {st }}$ & $1^{\text {th }}$ July & 7.50 & 76.69 & 0 \\
\hline 2. & $2^{\text {td }}$ & $1^{\text {st }}$ August & 8.72 & 74.42 & 0 \\
\hline 3. & $3^{\text {rd }}$ & $1^{\text {th }}$ August & 12.98 & 72.03 & 0 \\
\hline 4. & $4^{\text {th }}$ & $1^{\text {st }}$ September & 18.46 & 71.23 & 0 \\
\hline 5. & $5^{\text {th }}$ & $1^{\text {th }}$ September & 25.93 & 67.73 & 0 \\
\hline 6. & $6^{\text {th }}$ & $1^{\text {st }}$ October & 32.22 & 66.76 & 0 \\
\hline 7. & $7^{\text {th }}$ & $1^{\text {th }}$ October & 39.30 & 64.09 & 24 \\
\hline 8. & $8^{\text {th }}$ & $1^{\text {st }}$ November & 44.98 & 60.84 & 50 \\
\hline 9. & $9^{\text {th }}$ & $1^{\text {th }}$ November & 52.03 & 58.37 & 80 \\
\hline 10. & $10^{\text {th }}$ & $1^{\text {st }}$ December & 52.03 & 58.37 & 80 \\
\hline
\end{tabular}

\section{References}

BARNET, J.P., 1979. Maturation of tree seeds. In : Proceedings of a symposium on Flowering and Seed Development in Trees. South Forestry Experimentation Station, Miss State University, IUFRO, pp. 272-280.

BHARDWAJ, S.D., PANWAR, P., KUMAR, M., 2002. Physical and biochemical changes in seeds as a maturity indices for harvesting Albizia lebbeck seeds. Journal of Hill Research 18(1): 52-55.

BONNER, F.T., 1972. Maturation of corms of sweet gum and American sycamore seeds. Forest Science 18: 223-231.

BONNER, F.T., 1974. Maturation of acorns of cherry bark, water and willow oak. Forest Science 20: 238-242.

GRIFFIN, A.R., 1972. The effect of seed size, germination time and sowing density on seedling development in Radiata pine. Australian Forest Research 5(4): 25-28.

HARRINGTON, J.F., 1970. Seed and pollen storage for conservation of plant gene resources. In: Genetic Resources in Plants, their Exploration and Conservation. Handbook No 11. International Biological Programme, London.

HARRINGTON, J.F., 1972. Seed storage longevity. In: Seed Biology 3: 145-245.

ISTA, 1993. International rules for seed testing 1STA. Seed Science and Technology 21: 4-300.
JOSHI, G., 2000. Physiological investigation on germination and viability of Dalbergia sissoo Roxb. Seed for ex-situ germplasm conservation. Ph. D Thesis submitted to FRI-Deemed University, Dehradun.

SANTAPAU, H., HENRY, A.H., 1973. A Dictionary of the Flowering Plants in India. Publication and Information Directorate-CSIR, New Delhi.

SINGH, A., 2006. Status and propagation of Hackberry Celtis spp. A multipurpose tree species of Kashmir valley. M. Sc thesis submitted to Sher-e-Kashmir University of Agricultural Sciences \& Technology of Kashmir, Shalimar, pp. 37-42.

SINGH, O., KACHARI, J., 2006. Seed maturity indices in Khasi pine (Pinus kesiya). Indian Forester 132(12): 1689-1691.

SINGH, V., 1989. Seed maturity indices in spruce. Indian Forester 115(5): 342-347.

SORENSEN, F.C., CAMBELL, R.K., 1993. Seed weight, seedling size correlation in coastal Douglas fir, genetic and environmental components. Canadian Journal of Forestry Research 23(2): 275-285.

STEIN, W.I., SLABAUGH, P.E., PLUMMER, A.P., 1974. Harvest processing and storage of fruits and seeds, pp 300-320. In: Seed of Woody Plants in United States. Agricultural Handbook No. 450. USDA. Forest Service, Washington. DC. USA. 
STOECKLER, J.H., SLABAUGH, P.E., 1965. Conifer nursery practice in the Prairieplains. US Department of Agriculture Handbook 278: 93.

THAKUR, A., CHOWHAAN, P.H. KHOBRAGADE, N.D., SHARMA, P., 2000. Study on effect of time of seed collection on germination of Dipterocarpus retusus BL. Syn. D.1. Macrocarpus vesque 126(8): 799-800.

THOMPSETT, P.B., PRITCHARD, H.W., 1993. Water status changes during development in relationship to the germination and desiccation tolerance of Aesculus hippocastenum L. seeds. Annals of Botany 71: 107-116.
UPADHAYAY, L., SINGH, R.P., TEWARI, A., BISHT, S., SHAH, S., 2006. Seed maturation indicators in Bauhinia retusa Ham. in Kumaun central Himalayas. Indian Journal of Forestry 29(4): 367-371.

WILLIAM, R.C., 1985. A guide to forest seed handling with special reference to the tropics. Food and Agriculture Organisation Forestry Paper, 20/2, FAO, Rome.

Entregue para publicação em Dezembro de 2008 Aceite para publicação em Abril de 2009 